\title{
Management Knowhow Spillover from Foreign Direct Investment and Local Firm's Performance
}

\author{
M.D Wanjere
}

\author{
M. Kinoti ${ }^{2}$ \\ X.N Iraki ${ }^{2}$ \\ M. Ogutu ${ }^{2}$ \\ ${ }^{1}$ School of Business and Economics, \\ Masinde Muliro University of \\ Science and Technology, \\ Webuye, Kenya \\ ${ }^{2}$ School of Business, \\ University of Nairobi, \\ Nairobi, Kenya
}

DOI: https://doi.org/10.36941/mjss-2022-0014

\begin{abstract}
The paper investigates management knowhow spillover from foreign direct investment effect on local firms performance. Scholars seem to agree on the importance of foreign direct investment spillover for country's growth but opinions vary regarding its impact. The study sort to establish the effect of management know spillover from FDI on performance of manufacturing firms. Empirical and theoretical literature has been reviewed on the key constructs of the study and hypothesis formulated. The reviewed literature has led to formulation of a conceptual framework showing the link among key variable of study. The study population consisted of 100 companies with at least 10 percent or more foreign ownership and registered with Kenya Association Manufacturers. The study respondents consisted of the Chief Executive Officers or representative of the participating organizations. The data was collected on management knowhow spillover from FDI and its effect on local firm performance using a questionnaire. The data was analyzed using descriptive statistics, correlation and simple regression analysis. The study established that management knowhow was significantly correlated with manufacturing firm performance and the correlation coefficient shows the relationship was weak and positive. The management knowhow accounted for $6.6 \%$ of variation in performance $\left(R_{2}=0.066\right)$. The corresponding model was also found to be significant $(F=5.144, P<0.05)$ as well the coefficient for management knowhow $(\beta=0.252, t=2.268, P<0.05)$. The implication of these findings is that the country policy makers should not only concern themselves with attracting FDIs, but also in ensuring that they secure the spillover to local firms. Organisation and government need to put in place policies that encourage spillovers from MNEs.
\end{abstract}

Keywords: Foreign Direct Investment, Management Knowhow, Firm Performance 


\section{Introduction}

Since 1990s, the share of foreign direct investment (FDI) inflows to developing countries has increased with the UNCTAD figures showing that these countries controlled a bigger proportion of the global foreign direct investment inflows than was the case previously (UNCTAD, 2012). The reason for this increment is the effort made in developing countries to attract more FDI to close the capital deficiencies. However, there is a general disagreement among scholars on the role foreign direct investment play in host country's development. Some scholars have argued it has a favorable effect, while still others have stressed the relevance of the unfavorable consequences. Onyekwena (2012) support this assertion by noting that industrialized countries have over years' invested heavily in research and development (R\&D) activities, which has seen them upgrade their existing management systems and technical capacities.

According to Hallin and Lind, (2012) the effect of foreign direct investment on host country firms has split scholars with no clear consensus regarding its impact on local firms. In absence of a consensus among scholars, policy makers have tended to assume that FDI have positive effects on host country economies. Harding and Javorcik (2011); UNCTAD, (2012) observed that this assumption resulted to formulation of policies that attract foreign direct investment in many of these countries. Further, Yi, Zhigang and Lianming, (2017) noted that many less developed countries have embraced programs to appeal to foreign investors in the hope that this would give them the requisite technological capacities and skills to spur their local industry. As such decision makers in many developing countries have liberalized their economies in an attempt to draw more foreign direct investment with a singular hope that this would support their countries development agenda.

The focus of this paper is to examine the role of management knowhow spillover from foreign direct investment on the performance of Kenyan manufacturing firms. It sort to investigate whether foreign direct investment activities in the Kenyan manufacturing sector is linked to transfer of management knowhow to local firms and how this affected their performance. Drawing from theories of foreign direct investment, the study operationalizes FDI as a construct that act as a source of managerial knowhow to local manufacturing firms. However, in the setting of this study, our focus is foreign direct investment as a source of management skills, which would otherwise be difficult for countries like Kenya to acquire. This is in line with Onyekwena (2012); Muhammad and Kashif (2013); Leman and Ismet (2015) who suggested that foreign direct investment is an essential impetus to local firm's development as it facilitates access to managerial knowhow.

\section{Kenya's Manufacturing Sector}

The importance of the manufacturing sector to the transformation of our country cannot be gain said. Various government policy documents such as Vision 2030, National Trade Policy, Kenya Industrial Transformation Program and Buy Kenya Build Kenya developed to boost the manufacturing sector in the country (KAM, 2018). The government has refined Kenya's industrial policy to foster globally competitive companies, has instituted rapid sector-focused FDI attraction and created industrial zones and parks to promote manufacturing industries. The Manufacturing sector is one of the Big Four Agenda that is to drive Kenya Transformation Agenda (KAM, 2018).

The manufacturing sector in Kenya initially developed under the government policy of import substitution in 1967 . The key industrial activity consists of food processing industries such as grain milling, beer production and sugarcane crushing and the fabrication of consumer goods, such as assembly of vehicles from kits. Ngui, Chege and Kimuyu, (2016) noted that Kenya Industrial activities are largely geared to meeting the basic needs through provision of cheap consumer and services. The goal of the National Government is to increase the contribution of manufacturing sector to 15 percent of the GDP by 2022. To achieve this, the level of investment and managerial skills in the manufacturing sector need to increase sector. 


\section{Related Literature}

According to Gorg and Strobal (2001), FDI inflow lead to certain benefits, accruing into a nation as the foreign partners situated in the host nation can benefit local firms through management knowhow spillovers. These arise for the reason that MNCs usually bring some kind of firm specific assets (Markusen and Venables, 2002) which manifest themselves as superior marketing, management knowhow or production technology. This makes them an attractive supplier of superior management skills for less developed countries when compared with other form of investment like Portfolio equity, debt flows and domestic investment (Onyekwena, 2012). The intangible assets typifying FDI infer that it's a characterization of modern-day knowledge with probable benefits to host nations through the provision of innovations, superior managements and industrial know-how (Javorcik 2004).

Leman and Ismet, (2015) noted that multinational corporations a crucial FDI vehicle spends heavily in research laboratories distributed throughout the globe making them a significant source of fresh technologies, innovations new patent and fast tracking of modernization of infrastructure within host nations. The International Monetary Fund (2018) and Government of Qatar (2014) asserted that in addition to availing funds to host nations, FDI inspire associates to transfer management knowhow to host nations offering them prospects of stimulating their trade in the international market.

In contrast, Galina and Cheryl (2011) study of available literature on productivity spillovers of FDI presence in China found no indication of productivity spillovers from FDI, even with a richer data set. They attributed lack of spillover to organizational issues like poor human capital, which hinders the channel for spillovers and local firms capacity to take on new technologies. Further, Diyamett and Mutambla (2014) study on Tanzanian firms established that very few firms recognized FDI as the bases of technical capabilities achieved a fact revealed in their limited associations with foreign investors. Allais, (2012); Rasool and Botha, (2011) asserted that skill shortage impedes the positive results of FDI on Total factor productivity (TPF) and in extension a country's economic growth potential. Barrios, Görg and Strobl (2006) observed an insignificant link between these spillovers and performance of local companies in East-Central Europe.

Drawing from theories of foreign direct investment, the study operationalizes FDI as a construct that act as a source of managerial knowhow to local manufacturing firms. Foreign direct investment is seen as a significant element in the growth of developing economies as it provided the much needed management knowhow to the local enterprises (Markusen and Venables, 1999; Blomström and Kokko 1998). However, in the setting of this study, our focus is foreign direct investment as a source of management knowhow transfers, which would otherwise be difficult for countries like Kenya to acquire. This is in line with Onyekwena (2012); Muhammad and Kashif (2013); Leman and Ismet (2015) who suggested that foreign direct investment is an essential impetus to local firm's development as it facilitates access to managerial knowhow.

\section{Conceptual Framework and Hypothesis}

\subsection{Conceptual Framework}

According to Kombo and Trump (2009), the conceptual model is a set of general views and ideals extracted from important scopes of study and adapted in arranging a sub-sequent presentation. Drawing from FDI theories, the study conceptualized FDI as leading to management knowhow spillover to local firms in turn improving their performance. The framework is illustrated in figure I: Independent Variable Mediating Variable Dependent of variable. 


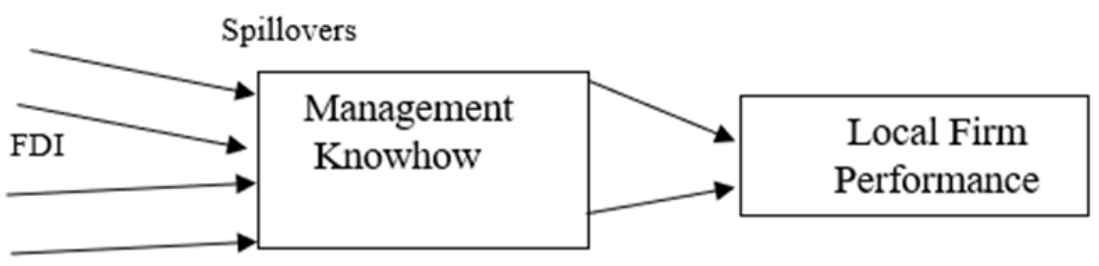

Spillovers

Figure 1: Conceptual model

Source: Researcher 2017.

The study hypothesis was stated as follows;

Management knowhow has no significant relationship with performance of manufacturing firms in Kenya.

\section{Methodology and Data}

This study adopted the positivist philosophy to study the relationships, test hypotheses and draw inferences. According to Paivi and Anne (2015), positivism is concerned with empirical verification of hypothesis from a theory. Positivist research embraces survey studies and allows researchers to use quantitative analytical techniques in their analysis. Further, it draws inferences from data to establish existing relationships.

To evaluate relationship among the research variables, correlational research design was used. According to Valmi, Martha and Isabel (2007) the design is useful in testing the relationship among variables to establish whether there is positive, negative or zero correlation. The investigators used the correlational statistics test to describe and measure magnitude of interaction among the variables. This design was appropriate because it facilitated exploration of the interplay between multiple variables and predict an outcome of one variable using knowledge of another variable.

The data was collected with the help of a survey questionnaire. The target respondents were the top managers conversant with the subject under study. The choice is similar to comparable researches undertaken by Shabarati, Jawad and Bontis (2010) who asserted that senior administrators are conversant with organizational features.

Data was pretested for normality, linearity, multicollinearity, autocorrelation, and homoscedasticity to safeguard against possible violations of the classical linear regression model (Cooper and Schindler, 2014). Normality of data was tested by use of histograms to determine whether or not the data used for the study was normally distributed. Under this test the data is assumed to be normal if histograms appeared symmetrical meaning that majority of the scores fell within middle region whereas fewer score were on both extremes.(Sekaran and Bougie, 2013), Multicollinearity was evaluated using Variance Inflation Factor (VIF). Levene's tests of homogeinity of variance were done to test homoscedasticity and heteroscedasticity.

The study used both descriptive and inferential tools to analyses the data. According to Kothari (2014), descriptive statistics is calculated to inform on the general trends and firm characteristics Correlation analysis was carried out to determine the extent to which one variable (predictor variable) was linearly related to the other variable (predicted variable), direction and strength of relationship. Tabachnick and Fidell (2013) posited that correlation analysis measures the extent and direction of the association between two constructs. Additionally, a series of regression models were fitted to the data in a bid to assess the association among the independent and dependent variables, and hypotheses tests done to establish whether the outcomes were significant or not. A summary of analytical procedures is presented in table 1. 
Table 1: Analytical Procedure

\begin{tabular}{|c|c|c|c|}
\hline Objective & Hypothesis & Hypothesis Test & Analytical model \\
\hline $\begin{array}{l}\text { Establish the } \\
\text { effect of } \\
\text { Management } \\
\text { Knowhow on } \\
\text { manufacturing } \\
\text { firm's performance }\end{array}$ & $\begin{array}{l}\text { Management } \\
\text { Knowhow has } \\
\text { no significant } \\
\text { effect on firm's } \\
\text { Performance. }\end{array}$ & $\begin{array}{l}\text { Simple regression analysis } \\
\mathrm{FP}=\beta \mathrm{o}+\beta \mathrm{MK}+\varepsilon \ldots \text { where } \\
\mathrm{FP}=\text { Firm performance } \\
\mathrm{MK}=\text { Management Knowhow } \\
\beta \mathrm{o}=\text { Constant (intercept) } \\
\beta \mathrm{I}=\text { Regression coefficient for } \\
\text { Management Knowhow, } \\
\varepsilon=\text { Error term }\end{array}$ & $\begin{array}{l}\text { Coefficient of determination } \\
\text { (adj. R2) value will illustrate the \% of } \\
\text { firm performance explained by } \\
\text { Management Knowhow. } \\
\text { Regression coefficient demonstrate } \\
\text { the variation in firm performance } \\
\text { due to a unit change in Management } \\
\text { Knowhow. }\end{array}$ \\
\hline
\end{tabular}

Source: Field Data (2019)

\section{Results and Discussion}

The study first undertook preliminary findings where emphasis was placed on the study's response rate and diagnostic tests. In the second section, the focus is on descriptive analysis of the data aimed at identifying basic and broad patterns. The third section considers more rigorous treatment of the data where mathematical modelling was invoked to explore the link between the variables of interest. The results of the analysis are presented in the preceding section.

\subsection{Preliminary Analysis}

Table 2: Data Entry Errors

\begin{tabular}{|l|c|c|}
\hline \multicolumn{2}{|c|}{} & FDIMK \\
\hline \multirow{2}{*}{ "N } & Valid & 75 \\
\cline { 2 - 3 } & Missing & 0 \\
\hline Minimum & & 5.00 \\
\hline Maximum & 25 & 15.00 \\
\hline \multirow{3}{*}{ Percentiles } & 50 & 11.0000 \\
\cline { 2 - 3 } & 75 & 13.0000 \\
\hline
\end{tabular}

Source: Field Data (2019)

Table 2 shows that the data set has no data entry errors. Management Knowhow had 75 valid responses and no data from respondents was missing.

\subsubsection{Screening and Preparation of Data}

Table 3: Outliers

\begin{tabular}{|l|c|c|c|}
\hline \multicolumn{4}{|c|}{ Descriptive Statistics } \\
\hline & $\mathrm{N}$ & Minimum & Maximum \\
\hline Zscore(FDIMK) & 75 & $\mathbf{- 2 . 8 8 5 2 1}$ & $\mathbf{1 . 0 5 6 3 3}$ \\
\hline
\end{tabular}

Source: Field Data (2019)

The table 3 designates the $\mathrm{Z}$ score (max. and min.) values for each of the singular variables. The table shows that the $\mathrm{Z}$ values of management knowhow are less than $+/-3$ meaning there were no outliers. 
Table 4: Range Values

\begin{tabular}{|l|l|c|c|}
\hline \multicolumn{2}{|l|}{} & FDIMKav & FPav \\
\hline \multirow{2}{*}{$\mathrm{N}$} & Valid & 75 & 75 \\
\cline { 2 - 4 } & Missing & $\mathrm{o}$ & $\mathrm{O}$ \\
\hline Minimum & 1.00 & 1.50 \\
\hline \multicolumn{2}{|l|}{ Maximum } & 3.00 & 3.63 \\
\hline
\end{tabular}

Source: Field Data 2019

The results in table 4 designates the average maximum and minimum scores for each of the variables. As manifested in table 4, the management knowhow scores from 1 to 3; and firm performance scores from 1.5 to 3.63 . For the likert scale adopted, the expected minimum values should be one (1) whereas the maximum value should be three (3).

\subsection{Diagnostic test}

The diagnostic tests were done to check the quality of the data and certify that the standard linear regression supposition was not violated. Normality was checked using histograms and the Kolmogorov-Smirnov test. The results of diagnostic analysis showed that the assumptions of normal distribution were not violated. Multicollinearity was verified in the model by examining the VIF scores and the results showed that the supposition of multicollinearity has not been desecrated in the study. The levene test was used to assess the homoscedasticity condition and the condition was not violated. The findings indicated that Management knowhow met the precondition.

\subsection{Descriptive Results}

The manifestation of management knowhow in the manufacturing companies was also examined. Hymer (1976) affirmed that FDI encompass the transfer of not only business oriented skills but skilled human assets as well. Management knowhow represents one of the critical resources instrumental in elevation of a company's competitive edge. Management knowhow was operationalised as staff training, mentorship by foreign staff and new quality management systems. Interviewees were required to evaluate whether introduction of FDI improved the management knowhow of their firms. The responses were subjected to a descriptive analysis and a breakdown of the results is illustrated in table 5 .

Table 5: Management Knowhow

\begin{tabular}{|l|c|c|c|c|c|}
\hline Management Knowhow & N & Mean & $\begin{array}{c}\text { Std. } \\
\text { Deviation }\end{array}$ & Variance & $\begin{array}{c}\text { Coefficient } \\
\text { of Variation }\end{array}$ \\
\hline In-house training programme for Kenyan staff & 75 & 2.48 & 0.86 & 0.74 & 0.30 \\
\hline Trained Kenyan staff on operational or production management & 75 & 2.51 & 0.86 & 0.74 & 0.30 \\
\hline Trained Kenyan staff on organizational management & 75 & 2.36 & 0.91 & 0.83 & 0.35 \\
\hline Mentoring of Kenyan staff by foreign staff in the firm & 75 & 2.43 & 0.89 & 0.79 & 0.32 \\
\hline Learned about new quality management system & 75 & 2.55 & 0.78 & 0.60 & 0.24 \\
\hline Overall & $\mathbf{7 5}$ & $\mathbf{2 . 4 6}$ & $\mathbf{0 . 8 6}$ & $\mathbf{0 . 7 4}$ & $\mathbf{0 . 3 0}$ \\
\hline
\end{tabular}

Source: Field Data (2019)

Overall, there was moderate ranking with regard to how FDI led to management knowhow in manufacturing companies in Kenya $(M=2.46, S D=0.86), C V=0.30)$. The statements FDI have made staff learn about new quality management system had the highest mean (mean $=2.55$ ), and also the 
lowest variations in responses $(\mathrm{CV}=0.24)$, an indication that the interviewees from the different organisation agreed with the statement. Other statement with a high mean rating was the item that FDI provided formal training for Kenyan staff on operational or production management at a mean of 2.51 and that the manufacturing firm introduced an in-house training programme for Kenyan staff at a mean of 2.48. The statement with the lowest mean in this category was that manufacturing firms provided formal training for Kenyan staff on organizational management at a mean of 2.36.

The above findings affirm the earlier assertion by Zou (2010) and Muhammad and Kashif (2013) that FDI is a source of managerial skills and that foreign direct investments transfers managerial knowhow to the local firms. The findings also agree with Javorcik (2008) who noted that FDI is a personification of superior management systems to host economies. Moreover, workers who move from FDI firms to local firms are able to transfer new management techniques.

\subsection{Correlation Analysis}

\subsubsection{Relationships between Predictor and Criterion Variables}

The objective of the correlation analysis was to determine whether spillover of management knowhow from FDI and firm performance are interrelated. It also seek to ascertain the strength and the direction of the relationship between the two variables. Based on the outcome, it is noted that performance was significantly associated to management knowhow $(r=0.25, p<0.05)$. The correlation coefficients also prove that the relationships were weak and positive. The outcomes of this study are shown in table 6.

Table 6: Correlation Analysis

\begin{tabular}{|c|c|c|c|}
\hline & & FDIMK & FP \\
\hline \multirow{3}{*}{ FDIMK } & Pearson Correlation & 1 & $.245^{*}$ \\
\hline & Sig. (2-tailed) & & .034 \\
\hline & $\mathrm{N}$ & 75 & 75 \\
\hline \multirow{3}{*}{ FP } & Pearson Correlation & $.245^{*}$ & 1 \\
\hline & Sig. (2-tailed) & .034 & \\
\hline & $\mathrm{N}$ & 75 & 75 \\
\hline
\end{tabular}

Source: Field Data (2019)

\subsubsection{Test of hypothesis}

The results pertaining to the assessment of the hypotheses set forth in this study are presented in this section. The overarching goal of the study was to investigate the linkage between management knowhow spillover from FDI and firm performance. It was hypothesized that management knowhow spillover from FDI has significant effect on firm's performance.

In the evaluation of the hypotheses, a set regression analyses were conducted at $5 \%$ level of significance. Specifically, simple linear regression was employed in the testing of the hypothesis. The results derived from the analyses is presented in the preceding section.

The study hypothesis was stated as follows;

Management knowhow spillover from FDI has no significant relationship with performance of manufacturing firms in Kenya.

The above hypotheses was tested using simple linear regression. A construct index for management knowhow was regressed on performance. From the results, management knowhow accounted for $6.6 \%$ of variation in performance $\left(\mathrm{R}_{2}=0.066\right)$. The corresponding model was also found 
to be significant $(\mathrm{F}=5.144, \mathrm{P}<0.05)$. Additionally, the model furnished a significant coefficient for management knowhow $(\beta=0.252, t=2.268, P<0.05)$.

The results are as shown in table 7 .

Table 7: Regression Results for management knowhow on firms performance

\begin{tabular}{|c|c|c|c|c|c|c|c|c|}
\hline & & & \multicolumn{2}{|c|}{ ANOVA } & \multicolumn{3}{|c|}{ Coefficients } & \multirow{2}{*}{ Resulting model } \\
\hline & Model & $\mathrm{R}_{2}$ & $\mathrm{~F}$ & Sig. & Beta & $\mathrm{t}$ & Sig. & \\
\hline \multirow[t]{2}{*}{4} & (Constant) & & & & 1.766 & 5.644 & & \multirow{2}{*}{$\mathrm{FP}=1.766+0.252 \mathrm{MK}$} \\
\hline & Management knowhow & 0.066 & 5.144 & $0.026 \mathrm{~b}$ & 0.252 & 2.268 & 0.026 & \\
\hline
\end{tabular}

Predictors: Management knowhow (MK)

Dependent Variable: Firm's performance (FP)

Source: Field Data (2019)

$$
\text { Management knowhow }
$$

Figure 2: Summary of resultant findings

Source: Field Data (2019)

The results from the test of hypothesis established that management knowhow $(\beta=0.252, t=2.268$, $\mathrm{P}<0.05$ ) had positive and significant impact on performance. These results confirm that management knowhow spillover from FDI increases performance of the local firms, denoting that FDI investments in a firm result to increase in their performance. The association between management knowhow and firm performance was found to be significant $\beta=0.252, \mathrm{t}=\mathbf{2 . 2 6 8}, \mathrm{P}<0.05)$ and had an explanatory power of $6.6 \%$. The findings agrees IMF (2018) observation that foreign direct investment benefits comes in form of sharing of management knowledge. The results also agree with the Government of Qatar, (2014) that noted that FDI inspire associates to transfer management know-how to host countries.

The findings contradicts Görg and Strobl (2006) who had earlier observed an insignificant link between these spillovers and performance of local companies in East-Central Europe and Galina and Cheryl (2011) study of available literature that found no indication of productivity spillovers from FDI to local firms even with a richer data set. The findings add to the burgeoning empirical base on management knowhow. The study provides a framework for understanding how management knowhow a variable of FDI may be appropriately regarded as a predictor of firm performance.

\section{Conclusion and Recommendations}

The concern of the study was to investigate the influence of management knowhow spillover from FDI on the performance of manufacturing firms in Kenya. To complete the analysis the study relied on descriptive statistics and regression tools. The results from the test of hypothesis established that management Knowhow spillover from FDI has positive association with firm performance.

The study has implications to theory, policy, and Managerial practice and contribute to knowledge. First, in terms of theory, the study enrich our understanding of our FDI theories which have been helpful in understanding the flow of FDI and spillover of FDI to the local indigenous firms. The results lend credence to the mushrooming empirical pedestals that validate the importance of FDI in the advancement of developing economies.

Secondly, in terms of policy, the study support the need for policy to encourage FDI inflow to the country. To achieve this, the authority should legislate a policy guideline to offer inducements and inspire foreign direct investments inflow to Kenya. There is need for formulation of broad range 
of policy framework to capitalize on the FDI spillovers to local manufacturing. This will help improve the management knowhow of the local firms.

Thirdly, the study has made serious contribution to knowledge in understanding of the role of FDI in the development of indigenous firms. The findings have demonstrated that FDI transfer management knowhow to local firms improving their performance. The current study also contributes towards addressing the gaps identified from the previous studies hence facilitating the growth of literature in the subject area and serves as a reference and base for other studies.

\section{Acknowledgements}

We thank all the manufacturing firms that took part in the study. Further, we acknowledge all the organizations that assisted with the logistics of data collection in particular Kenya Association of Manufacturer and Kenya Export Promotion Center. We thank you all!

\section{References}

Allais, S. (2012). Will skill save us? Rethinking the relationships between vocational education, skills development policies, and social policy in South Africa, International Journal of Education Development, 32(5), $632-642$

Barrios, S.,, Görg, H., \& Strobl, E., (2006), Multinationals' Location Choice, Agglomeration Economies, and Public Incentives, International Regional Science Review, Vol. 29, No.1, 81-107.

Blomström, M. \& Kokko, A. (1998). Multinational Corporations and Spillovers. Journal of economic Surveys, $12 / 2$.

Cabrita, R., \& Bontis, N. (2008). Intellectual capital \& business performance in Portuguese banking industry. International Journal of Technology Management, Vol.43, pp.212-237.

Cooper, D., \& Schindler, S. (2014). Business Research Methods. New York: McGraw-Hill Irwin.

Diyamett, B., \& Mutambla, M. (2014). Foreign Direct Investment and Local Technological Capabilitie in least developed countries: some evidence from the Tanzanian \manufacturing sector. African Journal of Science, Technology, innovation and Development, Vol l6, issue 5.

Galina, H., \& Cheryl, L.,(2011); Are there productivity spillovers from foreign direct investment in china? Pacific Economic Review, 16: 2 pp. 135-153.

Görg, H., \& Strobl, E. (2001). Multinational companies and productivity spillovers: A meta-analysis. Economic Journal, 111(475), pp.723-739.

Government of Qatar (2014). Foreign Investment Survey, 2013, Published by Ministry of Development Planning and Statistics State of Qatar, Doha.

Hallin, C., \& Lind, C. H. (2012). Revisiting the external impact of MNCs: An empirical study of the

mechanisms behind knowledge spillovers from MNC subsidiaries, International Business Review, vol. 21, issue 2, pp.167-179

Harding, T., \& Javorcik,B.S. (2011). Roll Out the Red Carpet and They Will Come: Investment Promotion and FDI Inflows, The Economic Journal, Vol. 121, Issue 557, pp. 1445-1476,

Hymer, S. (1976). The International Operations of National Firms, Ph.D. Thesis, Cambridege, MA:MIT ress.

International Monetary Fund. (2018). "Private Investments to Rejuvenate Growth". Regional Economic Outlok; subSahara Africa, Washington DC, April.

Javorcik, B. S., (2004). "Does Foreign Direct Investment Increase the Productivity of Domestic Firms? In Search of Spillovers Through Backward Linkages." American Economic Review, 94 (3): 605-627.

Javorcik, B. S., (2008). "Can Survey Evidence Shed Light on Spillovers from Foreign

Direct Investment”, World Bank Research Observer, vol. 23(2), pp. 139-159.

Kenya Association of Manufacturers. (2018). Manufacturing in Kenya Under the 'Big 4 Agenda'A Sector Deep-dive Report. Publication of Kenya Association of Manufacturers, Kenya.

Kenya National Bureau of Statistics, (2017). Economic survey report 2017.

Kombo, D. K., \& Tromp, L. A. (2009). Proposal and thesis writing: An introduction. Nairobi: Paulines publications Africa.

Kothari, C. R. (2014). Research Methodology: Methods and Techniques. New Delhi, India: New Age International Publishers. Second revised edition 
Leman, E., \& Ismet, G., (2015). The Effects of Foreign Direct Investment on R\&D and Innovations: Panel Data Analysis for Developing Asian Countries. World Conference on Technology, Innovation and Entrepreneurship. Procedia-Social and Behavioral Sciences 195, pp.749-758. Online at www.sciencedirect.com

Markusen, J.R. \& Venables,A.( (1999). Foreign direct investment as a catalyst for industrial development. European Economic Review, 43, 335-356.

Markusen, J.R. \& Venables,A. (2002). Multinational firms and Theory of International Trade, Cambridge MA, MIT press.

Muhammad, T. M., \& Kashif, R. (2013). Does Foreign Direct Investment Influence Economic Growth and Human Capital of Host Countries? A Review of Empirical Evidence. World Applied Sciences Journal. 21 (8), 1116-1121

Ngui, D., Chege, J., \& Kimuyu, P. (2016). Kenya's industrial development: policies, performance, and prospects, manufacturing transformation: comparative studies of industrial development in Africa and emerging, 72-91, Oxford University Press (C) Unu-Wider / Cc By-Nc-Sa 3.o Igo

Onyekwena, C. (2012), Empirical investigation of the impact of Foreign Direct Investment on manufacturing firms and banks in Nigeria, Unpublished PhD Thesis, University of Portsmouth.

Paivi, E., \& Anne, K. (2015). Qualitative Methods in Business Research: A Practical Guide to Social Research. $2^{\text {nd }}$ ed, SAGE Publications.

Rasool, F. \& Botha, C.J. (2011). The nature, extent and effect of skills shortage on skill migration in South Africa. South African Journal of Human Resource Management, 9(1), 1-12.

Sekaran, U., \& Bougie, R. (2013), Research Methods for Business-Skill Building Approach. (6th Ed.). John Wiley and Sons, West Sussex.

Shabarati, A., Jawad, J. \& Bontis, N. (2010). Intellectual capital and business performance in pharmaceutical sector of Jordan. Management Decision Journal, 48 (1), 105-13.

Tabachnick, B.G., \& Fidell, L.S.,(2013). Using multivariate statistics, $\left(6^{\text {th }}\right.$ ed.). Boston: Pearson.

UNCTAD (2012). Towards a New Generation of Investment Policies, World Investment Report 2012: Geneva: UNCTAD.

Valmi, D. S., Martha, D., Isabel, A.C.M. (2007). An overview of research designs relevant to nursing:

Part 1: Quantitative research designs. Rev Latino-am Enfermagem, maio-junho; 15(3),502-507.

Yi, L., Zhigang, T., \& Lianming, Z. (2017). "Identifying FDI Spillovers", Journal of International Economics, July, Vol. 107, 75-90.

Zou, Y. (2010). The impact of Inward FDI on Host country: Firm Performance in New Zealand. Unpublished Master of Commerce and Administration in International Business thesis, the Victoria University of Wellington 